\title{
Raja Karjalan kannakselaisten sukupolvien identiteettityön määrittäjänä
}

\author{
$y$ \\ Evakkojen rajakokemus on osa jälkipolvien psyykeä ja \\ mentaliteettia. Millainen vaikutus kahden valtakunnan ja \\ kahden kulttuurin välisellä rajalla on ollut eri Karjalan \\ kannakselaisten ja heidän jälkeläistensä identiteettiin?
}

"Elämäni ensimmäiset 20 vuotta olen elänyt itäisessä Suomessa, Kymenlaaksossa, lähellä sitä rajaa, johon sivistys minun lapsuudessani loppui. Rajan takana oli "Se", josta puhuttiin monimerkityksisin sanakääntein, jos puhuttiin. Vuosikymmenien ajan viralliset valtuuskunnat olivat ainoa mahdollisuus saada kosketusta "Sillä" puolella asuviin ihmisiin. Neuvostoliitosta saatavissa oleva kuva oli niin epäselvä ja lähihistoriasta löytyvät tapahtumat niin kipeitä, että kaikki minua kasvattaneet tahot katsoivat parhaakseen olla kertomatta aiheesta yhtään mitään." (Kivimäki 1999, 5.)

RAJA TARKOITTAA YLEISIMMIN konkreettista maastoon ja karttaan merkittyä joko luonnon muotoja seuraavaa tai muilla perusteilla määrättyä linjaa maastossa. Se on myös määräävä elementti monille muille rajakäsitteille. Karjalan Kannaksella valtakunnan raja merkitsi, ei vain aluetta vaan sosiaalisia, kulttuurisia ja symbolisia eroja.
Kannas oli "riitamaa", joka oli joutunut milloin Ruotsin, milloin taas Novgorodin tai sittemmin Venäjän ja Neuvostoliiton valtaamaksi. Historiallinen raja siirtyi useita kertoja ja siirtojen merkitys alueen asukkaiden elämään oli useimmiten merkittävä.

Venäjän vastainen raja oli Suomen autonomian alkuaikoina melko avoin liikenteelle, mutta tuli valvotummaksi ensimmäisen maailmansodan jälkeen ja sulkeutui lopulta merkittävästi Suomen itsenäistyessä. Totaalisesti raja sulkeutui toisen maailmansodan jälkeen.

Venäläistämisen kaudet 1800-luvun lopulla ja 1900-luvun alussa käänsivät rajaseudun asukkaiden suhtautumisen rajantakaiseen yhteiskuntaan aiempaa negatiivisemmaksi. Rajojen sulkeutuminen Neuvostoliiton aikana 1920-luvulta aina sen luhistumiseen asti 1991 merkitsi samaa etenkin, kun vapaa matkailu rajan yli ei ollut mahdollista. Joitakin virallisia delegaatioita otettiin vastaan ja kohteita näytettiin valikoidusti. Esimerkiksi turistibussin pysähtyminen ryhmäviisumissa mainitsemattomissa paikoissa oli 
kielletty. Viisumeja myönnettiin merkittävämmin vasta 1990-luvulla. (Koponen 1999, 7-8.) Raja oli suljettu myös arkeologeilta (Uino 2003, 143-145).

Artikkelissa kuvataan, miten rajaan liittyneet tapahtumat ja kokemukset ovat vaikuttaneet Karjalan Kannaksella asuneiden siirtokarjalaisten identiteettiin ja miten se näkyy kannakselaisen evakkosukupolven sekä heidän lasten ja lastenlasten identiteettityössä. Taustalla olevan tutkimuksen keskeisin löydös ja käsite on rajan imperatiivi ${ }^{1}$, joka on määrittänyt kannakselaisuutta useassa sukupolvessa ja johon tässä artikkelissa keskitytään.

\section{KARJALAISUUS MÄÄRITTYY ERI KARJALOIDEN POHJALTA}

Tutkijoiden teksteissä ei yleensä rajata, mitä nimenomaista Karjalan aluetta tutkimus koskee. Leea Virtanen $(1987,179)$ toteaa ylimalkaisuuden artikkelissaan Monta karjalaa: "Hämmästyttävän monien Karjala-käsitys on pääteltävä esitysyhteydestä. Se voi olla pikemmin utopia, kuvitelma yhtenäisestä kansasta, joka heltyy yhtä helposti iloon kuin kyyneliin." Hän kirjoittaa, että ensiksi tutkijan on sidottava sanomansa nimettyyn erityisalueeseen ja historialliseen todellisuuteen - Karjala on vain erilaisten kielten ja kulttuurien kattonimitys. Toiseksi Suomessa on "varovasti arvioiden ainakin miljoona kansalaista, joilla ei ole mitään käsitystä luovutetusta Karjalasta tai Inkerin kansankulttuurista” - vanhaa Karjalaa ei tunneta sen yleissivistyksellisestä merkityksestä huolimatta. Kolmanneksi karjalaisen kansanelämän dokumentointi on puutteellista ja toisinaan romanttisen innostuksen leimaamaa - keskeisistäkin ongelmista yksittäinen tutkija tai lukija joutuu noukkimaan sirpaleista tietoa eri tahoilta. (Mt., 185.)

Sodan ja rauhanteon seurauksena menetetty Karjala ei ollut laadullisesti yhtenäinen alue. Erkki Paavolainen (1960, 5-6) on jaotellut menetetyn Karjalan kolmeen alueeseen: Etelä-Karjala (Viipurin Karjala, Kannas ja ulkosaaret), Keski-Karjala (Vuoksen keskivaiheilta Kurkijoen ja Parikkalan rajoille) ja RajaKarjala (Laatokan luoteis- ja pohjoisrannikolta itärajalle). Heikki Waris (1952, 39-40) on nimennyt Keski-Karjalaksi pääosat vanhimmasta karjalaisten asuma-alueesta, joka lisäksi oli kehittyneintä maa- talousaluetta, mutta samalla myös teollisuusaluetta. Toisinaan $^{2}$ taas puhutaan Kannaksesta ja Laatokan Karjalasta, jolloin myös Raja-Karjala käsitetään Laatokan Karjalaksi.

Kannaksen rajaseutu ja Raja-Karjalan seutu olivat historiallisesti, asutuksellisesti, kielellisesti, kulttuurisesti ja taloudellisesti erilaisia alueita vielä 1900-luvun alussa ja itsenäisyyden ensimmäisinä vuosikymmeninä. Raja-Karjala oli vielä vuonna 1939 melko harvaan asuttua, kun sitä vastoin Kannaksella ei ollut laajoja syrjäseutuja. Kannas olikin ennen talvisotaa yksi Suomen tiheimmin asutuista alueista. (esim. Raivo 1988, 15; Engman, 2007.)

Kannas oli koulutuksen ja muun opillisen sivistyksen osalta kehityksen etulinjassa. Esimerkiksi ensimmäinen tyttökoulu perustettiin Viipuriin jo vuonna 1788 , mutta tyttöjä oli otettu eräisiin kouluihin jo 1600-luvulla. Viipurin ja sitä ympäröivän läänin koulut oli tarkoitettu kaikkien yhteiskuntaryhmien lapsille. Reaaliaineiden ottaminen koulujen ohjelmaan ja erillisten reaalikoulujen perustaminen tuli muualle Suomeen vasta 1870-luvulla. (Hietala 1982, 53-69.)

Selkein kulttuurinen ero kannakselaisten ja rajakarjalaisten välillä oli kuitenkin uskonnollinen. 1930-luvulla Raja-Karjalassa oli runsaasti ortodoksista väestöä, josta osa puhui karjalankieltä (Mäkinen 1982, 448-459). Vastaavasti Kannaksen valtaväestö oli luterilaista.

\section{IDENTITEETTI JA IDENTITEETTITYÖ}

Identiteetin määritelmiä on monia. Tutkijat määrittelevät identiteetin riippuen tieteenalasta, näkökulmasta tai tutkimustehtävästä, kuten esimerkiksi ryhmäidentiteetti tai sosiaalinen identiteetti, yhteisyysidentiteetti, kulttuuri-identiteetti (Sallinen-Gimpl 1989, 210; 1994, 40-43), kollektiivinen identiteetti, sosiaalinen identiteetti, henkilökohtainen identiteetti ja minä-identiteetti (Houtsonen 1996, 203-210; Anttila 2007, 10-15) sekä narratiivinen identiteetti (Huotelin 1996, 24-25). Myös alue ja kotipaikka voivat olla identiteetin määrityksen perustoina, jollaiseksi Anssi Paasi (1984, 50-52) nimeää alueellisen identiteetin.

Honko $(1988,13)$ arvioi, että yksilöidentiteettiä on tutkittu enemmän kuin ryhmäidentiteettiä ja että 
suurin osa, ellei kaikki, ryhmäidentiteettiä koskeva empiirinen tieto perustuu yksilö- tai niin sanottuun elitistiseen identiteettitutkimukseen. Myös Lehtonen $(1999,6)$ toteaa identiteettien moninaisuuden tutkimisen ongelmallisuuden. Yksilöpsykologiassa kohteena on minä- tai itseidentiteetti, sosiaalipsykologiassa sosiaalinen identiteetti ja sosiologiassa identiteettirakenteet ja -prosessit. Symbolisen interaktionismin pääsuuntauksen sisällä Iowan koulukunnan rakenneinteraktionistit puhuvat rooleista ja Chicagon koulukunnan prosessi-interaktionistit korostavat identiteettineuvotteluja (Liebkind 1988, 62).

Anttila (2007) määrittelee kansallisen identiteetin yhteisesti jaettuna merkitysmuodostelmana, joka lähtee yksilöstä, identifioijasta itsestään. Ihmiset samastuvat kansakuntaan kansallista identiteettiä koskevan käsityksensä mukaisesti. Identiteetti on tietoisuutta itsestä ja omasta kulttuurista jonakin toisista kulttuureista poikkeavana ja omasta paikasta siinä. Kollektiivinen identiteetti on kansallisen identiteetin rinnakkais- tai yläkäsite. (Mt., 2007, 3-5, 33-36.)

Siten identiteetti määräytyy sekä yksilöllisesti että sosiaalisesti. Sosiaalinen liittyy kansalliseen ja alueelliseen, suvun perintönä saatuun identiteettiin. Alueellisen identiteetin perusta on etnisyydessä, jonka voi olettaa ilmentävän vanhempaa ja voimakkaampaa identiteettityön lähtökohtaa verrattuna muihin identiteettiperustoihin. Näin ollen kannakselaisuus on rinnastettavissa kansalliseen identiteettiin suomalaisuutena, jonka määritelmät sopivat monin osin myös maakuntaperustaisen kannakselaisuuden käsitteisiin.

Wengerin $(1999,154)$ mukaan identiteetti on pohjimmiltaan ajallinen ja identiteettityö jatkuvaa. Koska identiteetti rakentuu oppimisen ja kehittymisen sosiaalisessa kontekstissa, identiteettityön käsite on huomattavan kompleksinen verrattuna suoraviivaisiin ajallisiin tulkintoihin. Siirtokarjalaisten oli uusissa asuinyhteisöissä löydettävä oma paikka, mikä tarkoitti sekä uuden kohtaamista eli akkulturaatiota että uuteen sulautumista eli assimilaatiota (vrt. Koiranen 1996, 3-8). Sosiaalistuminen uuteen yhteisöön ja kulttuuriin edellytti enemmän tai vähemmän tietoista identiteettityötä ei vain oman vaan myös tulevien sukupolvien kokemuksena.

\section{Identiteettikriisit}

Heikki Kirkinen (1998) käsittelee identiteettikriisin käsitettä karjalaisten historiaan liittyneinä identiteettikriiseinä. Ensimmäinen niistä alkoi jo ristiretkiajalla ja huipentui vuonna 1323, kun Karjala jaettiin ensimmäisen kerran kahtia. Pähkinäsaaren rauhansopimus johti karjalaisen identiteetin jyrkkään hajoamiseen ja kahden toisilleen vihamielisen karjalaisen identiteetin muodostumiseen. Toinen kriisikausi liittyi Stolbovan rauhaan vuonna 1617, kun Ruotsi sai Venäjältä valloittamansa Käkisalmen läänin ja Inkerinmaan. Ruotsi verotti raskaasti alueiden asukkaita ja pyrki käännyttämään ortodoksista väestöä luterilaiseen uskoon, jolloin ortodokseja pakeni joukoittain Venäjälle. Kolmas identiteettikriisi syntyi myös rajojen muuttamisen myötä, kun Suomesta tuli autonominen suuriruhtinaskunta vuonna 1809 Haminan rauhansopimuksen jälkeen. Eri karjalat löysivät yhteisyyttä, kun uhkana koettiin Venäjän panslavistisen liikkeen pyrkimys venäläistää vähemmistökansoja. Neljäs identiteettikriisi eskaloitui vuonna 1939 liittyen kiinteästi talvi- ja jatkosodan sekä rauhanteon vaiheisiin. (Mt., 42-51.)

Karjalaisten uusi tilanne sodan alta kotiseudulta paenneina ja muihin maakuntiin joutuneina aiheutti jälleen identiteetin järkkymisen. Sen lisäksi väestön enemmistöön sekoittuminen loi aikaisemmista kriiseistä poikkeavan identiteettityön, sopeutumisen, sulautumisen ja selviytymisen paineen. Siten neljäs identiteettikriisi ja sen aiheuttamien karjalaisten elämänkriisien käsittely jatkuu yhä psykologisella, sosiaalisella, kulttuurisella ja poliittisella tasolla.

\section{Kannakselaiset sukupolvet tutkimuksen kohteena}

Sukupolven käsitettä ilmentää yhtältä biologinen, esivanhempien, isovanhempien, vanhempien, lasten, lastenlasten ja niin edelleen sukupolvijatkumo ja -verkosto, johon liittyy aina uusia sukuja, kun lapset ja seuraavat sukupolvet muodostavat uusia perheitä. Toisaalta sukupolvi on yhteiskunnallista ja poliittista kokemusta ilmentävä käsite, joka perustuu historiallisten muutosilmiöiden rytmittämiin aikajaksoihin ja määrittyy syntymäajan mukaan (Mannheim 1972). Purhonen $(2007,85)$ liittää käsitteeseen diskursii- 
visen ulottuvuuden, mikä tarkoittaa sukupolvikokemusten artikulaatiota: jotta sukupolvitietoisuus ja kollektiivinen identiteetti voi syntyä, jonkun tai joidenkin on täytynyt koota ne.

Roos (1987) määrittää neljä yhteiskunnallista sukupolvea tai ikäkohorttia ${ }^{3}$, joita ovat (1) sotien ja pulan sukupolvi, (2) sodanjälkeisen jälleenrakennuksen sukupolvi, (3) suuren murroksen sukupolvi ja (4) lähiöiden sukupolvi. Kasvatustieteessä kokemuksellisten sukupolvien käsitettä on käyttänyt muun muassa Kauppila (1994; 1996) nimeten ennen vuotta 1935 syntyneen sodan ja niukan koulutuksen, vuosina 1935-1955 syntyneiden rakennemuutoksen ja kasvavien koulutusmahdollisunksien ja vuonna 1956 ja sen jälkeen syntyneiden hyvinvoinnin ja monien koulutusvalintojen sukupolven.

Artikkelin taustalla olevassa tutkimuksessa (Ilonen 2013) biologisten sukupolvien ketju rinnastettiin kokemuksellisten sukupolvien ikäkohortteihin (vrt. Kujala 2003, 141), jolloin haastateltujen henkilöiden elämää järisyttäneet kokemukset korostuvat ja vaikuttavat sukupolvien ylitse (ks. Kuvio 1). Koko tutkimuksen pääkysymys kuului: Miten Kannaksen siirtokarjalaiset tekevät identiteettityötään?

Tutkimus kohdentui kannakselaisten ja heidän jälkeläistensä kokemusperäiseen identiteettityöhön, jolloin tutkimusotetta voi luonnehtia laadulliseksi, aineistolähtöiseksi ja konstruktiiviseksi (vrt. Denzin \& Lincoln 2005) sekä myös biografiseksi elämäkertaa sivuavien kirjoitusten, kertomusten ja haastattelujen vuoksi (esim. Metsämuuronen 2007, 212-214).

Tässä artikkelissa keskitytään tutkimuksen tärkeimpään löydökseen, kannakselaista identiteettityötä määrittävään rajan imperatiiviin, joka kertoo, millainen vaikutus kahden valtakunnan ja kahden kulttuurin välisellä rajalla on ollut ja yhä on kannakselaisuutta uusintavan ja uudistavan identiteettityön muotoutumisessa. Rajan imperatiivi on käsite, jota ei sellaisenaan löydy muusta kirjallisuudesta. Taustalta löytyy kuitenkin moraalifilosofinen kategorisen imperatiivin käsite (Kant 1990), jota on heuristisesti sovellettu tässä tutkimuksessa ${ }^{4}$.

Vanhimman sukupolven edustajat valikoituivat tutkimukseen niin sanotulla lumipallomenetelmällä. Valinta ei kuitenkaan tapahtunut jokaisen edellisen haastatellun ehdotuksesta, vaan ehdottajia oli muitakin, kuten pitäjäseuran toimihenkilö kahden pitäjän osalta. Ikäpolven vanhin henkilö oli haastatteluhetkellä 94-vuotias ja nuorin 63-vuotias. Seuraavaksi haastateltiin toiseen sukupolveen kuuluvat vanhimman sukupolven lapset ja kolmanteen polveen kuuluvat lastenlapset.

Kokonaisia sukuja haastatelluissa oli 12 , joista kuuden suvun kaikki elossa olevat edustajat olivat tutkimuksessa mukana. Vajaita sukuja oli 13, joista seitsemää edusti ainoastaan vanhin sukupolvi. Haastateltuja oli 111 henkilöä, joista 29 kuului ensimmäiseen, 40 toiseen ja 41 kolmanteen sekä $1^{5}$ henkilö neljänteen sukupolveen.

Aineisto kerättiin avoimin haastatteluin, mikä salli myös niiden täydentämisen teemahaastattelulla ${ }^{6}$. Vanhimman sukupolven haastattelu oli puhtaimmin avointa kertomista (vrt. Raninen-Siiskonen 1999), mutta seuraavien sukupolvien kohdalla se oli dialogimaista vuoropuhelua liittyen asioiden selventämiseen. Keskusteluteemojen asettaminen oli tarpeellista erityisesti toisen ja kolmannen sukupolven haastatteluissa (vrt. Eskola 2000, 85-94). Haastatte-

$>>>>>$ Biologisten sukupolvien ketju $>>>>>>$

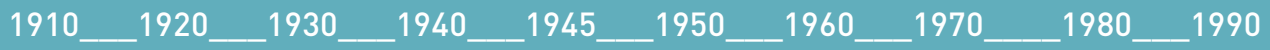

Kuvio 1. Biologiset sukupolvet rinnastettuina ikäkohortteihin. 
lut litteroitiin ja koodattiin käyttäen sisällönanalyysin menetelmää (Tuomi \& Sarajärvi 2009, 74-77, 101-113).

\section{RAJAN IMPERATIIVI - KANNAKSELAINEN PERUSKOKEMUS}

Analyysin tulokset tiivistyivät kahteen identiteettityön kollektiivisuutta ilmentävään kategoriaan (ks. Kuvio 2). Arvojen ylläpitäminen, sosiokulttuurinen aktiivisuus ja rajan imperatiivi ilmentävät haastateltujen kokemukseen perustuvaa kannakselaista tunnekollektiivisuutta. Vastaavasti kannakselainen perinteen vaaliminen, aktiivinen kansalaisuus ja tietoinen kasvatus ylläpitävät tietoon perustuvaa toimintakollektiivisuutta.

Rajan imperatiivi poikkeaa luonteeltaan ja merkitykseltään identiteettityötä määrittävistä muista luokista ja kategorioista. Se on sisällöltään negatiivinen verrattuna muihin kannakselaisuutta määrittäviin perustekijöihin. Etenkin vanhimman sukupolven mielissä raja muistettiin ${ }^{7}$ kielteisenä asiana, jota kuvattiin rajan kirona, sotakokemuksena, evakkoon joutumisena. Positiivisten määrittäjien negaationa raja ansaitsee erillisen tarkastelun.

\section{Sota- ja evakkokokemukset}

Rajan negatiivinen merkitys on ollut evakkojen mielissä tunnetason kauhukokemuksista seurannut tila. Alaluokkaa ${ }^{8}$ rajan kammo kuvaavat aineistosta poimitut pelkistetyt ilmaukset.

"Siellä sit tapahtu niitä asioita. Täyty kärsii niitätappoja." (RKi 7.)
"Rajan lapsen elämä ei olt nii mukavaa." (RKi7 1.)

"Ei yhtää hää rajalle päi lähe." (Lkä11.)

"Viimesinä vuosina äiti ei päästänyt Rajajooel mattoja pesemää. Turvaton olo rajan takana." (RKi5, 1.)

Vieraan vallan alle jäämisen mahdottomuus oli itsestään selvää. Rajakokemukset muokkasivat pelon kautta suhtautumistapoja mutta myös isänmaallisuutta. Ahokkaan (2004, 66-67) mukaan poliitikot olisivat halunneet karjalaisten jäävän tai palaavan uuden rajan takaisille alueille, mutta sinne ei haluttu eikä Neuvostoliittokaan ollut siihen halukas.

"Ei ne sinne venäläisten alaisuuteen mene." (VuVr1 12.)

"Ko vanhat rajat palautus ja Karjala tulis Suomel. Sinne olis mänijöi." (VuVr2 12.)

"Ymmärrettii, että tätä maata täytyy puolustaa ja siellä (rintamalla) täytyy olla, koska se, jota vastaan puolustettii, se oli venäläine kommunismi...ja se ruokki sellasta isänmaallisuutta samalla. Ei se tullut koskaan esille tämä asia sillä tavalla, ett oliko sitte justii konkreettisesti omaa maata. Se oli se Suomi, joka oli yhteinen kaikil niin kyllä se oli yksmielistä. Ja sillähän siellä pärjättii." (RU2, 6.)

Vanhimmilla miehillä ja osalla vanhimmista naisista sotakokemukset olivat todellisia monivuotisilla sotatantereilla sotilaina ja lottina. Sotakokemukset tuottivat rajaseudun pitäjien asukkaille välitöntä kuoleman kauhua - myös pikkulapsina.

"Sieltä Koivistolta mie muistan sen, että pöyvän alla oltii piilossa ja äiti veti minnuu käsvarresta kellarii.
KOKEMUKSEEN PERUSTUVA

TUNNEKOLLEKTIIVISUUS

Rajan imperatiivi

Sosiokulttuurinen aktiivisuus

-Arvojen ylläpitäminen
TIETOON PERUSTUVA

TOIMINTAKOLLEKTIIVISUUS

- Perinteen vaaliminen

- Aktiivinen kansalaisuus

- Tietoinen kasvatus

Kuvio 2. Identiteettityön peruskategoriat ja pääluokat 
Ni ne on niiko semmoset kuvat, että piiloo piti mennä. Ja kerrakii oltii oltu jossain kiven takana piilossa. miun tuonne sisimpääni on jääny ne kauhukuvat ihan sellane niiko kuoleman tunnelma." (Ko2, 1.) Kotoa lähdön tunteista kertoi harva haastateltu, mutta sen sijaan kerrottiin lukuisia tarinoita evakkoelämästä, joka oli paikasta toiseen siirtelemistä. Sotatalvi oltiin yhdessä paikassa ja keväällä tai myöhemmin siirryttiin toiseen, kunnes jatkosota syttyi ja kääntyi pian Suomen etenemiseksi talvisodassa menetetyille Karjalan alueille? . Korsuissa ja pahviparakeissa tai muissa väliaikaisissa kojuissa asuen haluttiin viljellä Kannaksen peltoja ruokapulan torjumiseksi.

Jatkosodan taistelulinjojen murruttua 1944 rajapitäjien asukkaille koitti jälleen uusi evakkomatka, joka kesäaikaan oli helpompi kuin ensimmäinen talviaikaan tehty evakkomatka. Karjaakin voitiin ottaa mukaan.

"... Mut mie tulin 500 kilometrii lehmii kans kävellen. Ni se ol taival. Myö oltii kolme päivää Punnuksen asemal. Meitä oli viis paimenta. Tultii sanomaa, ettei ennää tule junnaa, et tehkää lehmii kans, mitä haluatte. Sitä en muista, mistä myö saatii niille vettä. Tienviitas oli $120 \mathrm{~km}$ Mikkelii. Ai ko myö oltii hyvillää, ko ol ennää $120 \mathrm{~km}$. Nyt ei männä sitä polkupyörälläkkää." (RKi 7.)

Jälkipolvien tiedot ja kommentit vanhempien ja isovanhempien evakkokokemuksista vaihtelivat. Ainoastaan muutamat toisen ja kolmannen sukupolveen kuuluvista mainitsivat niistä.

"On se kovaa ollut...vanhemmillani, kun he on joutuneet kotinsa jättämään. Mun isä on kertonut, kuinka pieni hän oli, kun oli joutunut kodin jättämään, ja huolehti äidistään ja ko äitikin on joutunut jättämään ja miten he hoiti sen tilanteen." (LKa42, 1.)

Sodan jälkeen pelot jatkuivat, koska rajan takana oleva yhteiskunta oli yhä arvaamaton. Vasta 1980-luvulla tilanne hieman helpottui, sillä matkailu rajan taakse mahdollistui, mutta pääsy valtateistä sivussa oleville kotipaikoille oli kielletty. Kotipaikoille pääsi vain salaa, jos uskalsi lähteä seikkailemaan. Pelko välittyi ja ulottui myös nuorempiin sukupolviin.

\section{Korvike-Karjala ja kotiseutumatkat}

Asuinpaikan löytyminen pienentyneessä Suomessa oli päätepiste evakkokierroksille, mikä tuntui hyvältä, vaikka uusi paikka oli monille vain maapala. Kun sitten oli pellot raivattu ja rakennettu uusi koti talousrakennuksineen, elämä tuntui vakiintuneen - ulkonaisesti.

"Pala Karjalaa piti jokaisen lapsen saada, ja niin jokainen sisarus sai hehtaarin palan kesämökkiä varten. Itse rakennettu mökki on myös tärkeä Karjalan korvike." (VuA3, 4.)

Myös monet jälkipolviin lukeutuvat arvostavat vanhempiensa ja isovanhempiensa itse raivaamaa ja rakentamaa tilaa ja tulevat satojen kilometrien päästä lähes viikoittain lapsuutensa kotitilan maille rakentamaansa loma-asuntoon.

"Kyl ne juuret meillä lapsilla et ne on niinku täällä... Toisaalta tietenki kunnioittaa ... vanhempien käymää tietä, joka ei oo helppo ollut, että tota tää on tietyllä tavalla meijän Karjala. Ja jotenki tuntee, että uus siirtolainen on... Kyl tänne haluu tulla ja ihanaa, että pääsee tulemaa. Tää on hirveen tärkee. Mä oon syntynyt ihan siinä talossa. Meidän mökki on ihan tossa mäen takana, et suorinta tietä on puol kilometriä." (VuVr1-24, 2.)

Evakoista muutamat eivät halua mennä vieraan maan hallitsemalle Kannakselle. He tietävät, että rakennuksia ei kotipaikalla enää ole tai jos on, ne ovat hoitamatta. He haluavat pitää kaiken vain muistoina kodista sellaisena kuin se oli silloin, kun sieltä jouduttiin lähtemään.

"Se siis niiko lamaannutti minut. Ja sit oli siinä oliks se neljä henkilöä muitakii ja sit ko mäntii, rakennukset oli --. Sitte ko valkeni, missä myö oltii, ni sitte avattii sampanjapullo ja tyhjennettii se siinä raunioilla. Mulle riitti se. Se oli niiko piste tälle asialle." (RR2, 3.)

Kun raja aukeni aiempaa enemmän 1990-luvulla, toisen ja kolmannen sukupolven matkat suvun kotiseudulle lisääntyivät runsaasti. Raja on kuitenkin edelleen raja liikkumisen rajoittamisen merkityksessä. Viisumien ja passien tarkastukset rajalla ja matkan 
kuluessakin viivyttävät matkaa ja tuntuvat turhilta toimenpiteiltä verrattuna Suomen länsirajan käytäntöihin.

" mutta sitte se reissu, missä äiti oli mukana ja yks, missä mummo ja pappa oli, ni ne ei ollut välttämättä semmosia kauheen kivoja muisteltavia. Se että ne paikat oli, mutta se arki siellä tänhetkisessä Karjalassa, että he ei kokenut sitä kovin rauhalliseks, että esimerkiks bussi oli pysäytetty ja oli vaadittu jotain tietullia ja jollakin oli ollut ase siellä ja se oli jotenkin, mitä äiti ja mummo kerto niistä... Ja mummo ja pappa sano, että nyt tais riittää Ja ehkä joskus, jos kuulostaa siltä, että siellä voi matkustaa turvallisesti saattaisin mennä." (VuVr1-211,3.)

Kotiseutumatkoille on viime aikoina otettu mukaan enenevästi aivan nuoria ja lapsia, jotka ovat evakkojen jälkeläisiä kolmatta tai neljättä sukupolvea. Näillä matkoilla vanhemmat ja isovanhemmat kertovat seuraaville sukupolville Karjalasta ja suvun kotipaikalla elämisestä siellä paikan päällä.

"Kyllä se on ilahduttava asia, karjalaisuudessa, että kun kesäkuun kahdeksas käytii siellä, ni on se, että... karjalaisuus jatkuu, koska siellä nyt niiko joka kerta on jopa kolmatta polvee mukana." (LKa2, 8.)

"... kylän maisemia katsellessa tuli sellainen tunne, että vasta nyt palapelin palat alkavat loksahdella kohdalleen, kun vihdoin lapsuuden aikana kuullut kertomukset saavat puitteet... Yhteenkuuluvuuden tunne oli myös ennen kokemattoman voimakas... Olen varma että haluan kierrellä Kannaksella enemmänkin tulevaisuudessa. Tuntuu pahalta, että Karjala sodassa menetettiin, se on yhä verta vuotava haava kaikille siellä syntyneille." (RKi32, 2.)

Kannakselaisten ja sieltä juurensa saaneiden matkat oikealle kotiseudulle ja vanhempien kotipaikoille ovat viime vuosikymmeninä muodostuneet sekä vanhimman sukupolven että jälkipolvien henkilökohtaisen identiteettityön muodoksi. Vanhin sukupolvi on aluksi käynyt kotiseutumatkoilla ikään kuin pyhiinvaelluksena - itsensä takia. On selvitetty suhdetta kotiseutuun ja kotipaikkaan.
"Ja ollaa käyty siellä ja viety sinne kotipaikoille. Meil on kuus lasta ja ne kaikki olleet siellä mukana. Ja kyllä tuntuu nyt, et hyökii tietäät, missä ne juuret ett siellä ne juuret ovat." (VuVr1-2,2.)

"Näen karjalaisuuden tietynlaisena menetettynä identiteettinä. Papasta selvästi puuttuu tietty osa, jota hän voi ainoastaan sanoin yrittää kuvailla meille jälkeläisille." (RKi512,1.)

Haastatelluista evakoista ne, jotka edustivat edellä mainittuja täysiä sukuja, oli kotipaikoillaan Kannaksella käynyt hieman enemmän kuin kaksi kolmesta $(68,75 \%)$ ja heidän lapsistaankin lähes kaksi kolmasosaa. Myös kolmannen sukupolven informanteista oli yli neljäsosa käynyt isovanhempiensa kotipaikalla. Vajaissa suvuissa 12 haastateltua 14:stä ja heidän lapsistaan ja lastenlapsistaan kolme neljäsosaa on käynyt vanhempiensa ja isovanhempiensa kotipaikoilla, mikä ei kuitenkaan ole kovin merkittävää, koska tutkimukseen osallistuneista heidän jälkeläisiään oli vähän.

\section{Kylähistoriat, sukukirjat ja symbolit}

Kannaksen alueelta on julkaistu kuvateoksia, paikallishistoriaa, muistelmia ja lehtiä evakkouden alkuajoista lähtien. 1950-luvulla ryhdyttiin julkaisemaan pitäjähistorioita ja 1980-1990-luvuilla Kannaksen kylien muisteluun ja historiaan liittyviä julkaisuja. Kannaksella ilmestyneitä pitäjälehtiä on elvytetty ja perustettu uusia kannakselaisen pitäjän nimeä kantavia lehtiä, joista osa ilmestyy edelleen kuukausittain tai jopa viikoittain.

Tutkimusaineistossa nousi esiin kirjojen tekeminen kotikylien ja sukujen perinteen ja historian tallennuksessa. Vanhimmassa sukupolvessa oli ainakin viisi sukukirjojen tekijää tai kotikylän historian ja muistojen tallentajaa, joiden työn tuloksista myös jälkeläiset ovat tietoisia.

"Ja nyt oli mulle ihan yllätys, kun... suvusta on tekeillä sukukirja ja pariin kertaan on tullut semmonen ote ja pyydetään tekeen korjauksia Hei on sukuseura, ni siit oli kanssa. Mä tykkäsin katsella ja korjata. Mä laitoin kaikki korjaukset ja mä tykkäsin siit. Ja kun mummo ja pappa on joltain kautta sukua toisilleen, niinku voi ajatellakin, kun on sa- 
malta alueelta onks he nyt sitten pikkuserkkuja tai se ei oo enää ihan se oma perhepiiri, vaan muutenki se on ehkä sitten aikuisena tullut semmoseks yleisemmäks kiinnostukseks." (VuVr1-211,3.)

Karjalaista identiteettiä korostetaan tietoisesti eri tavoin. Lippumenot karjalaisin pitäjä-, suku- ja kuorolipuin on tapa tärkeissä juhlatapahtumissa. Yksi näkyvimmistä tavoista on kansallispuvun käyttö erilaisissa juhlissa. Haastatteluissa tuli selvästi esille kansallispuvun tai muun karjalaiseen tyyliin runsaasti kirjotun puvun arvostus. Kolme haastateltua myös esitteli pukunsa konkreettisesti haastattelun yhteydessä. Kotiseudun kansallispuvun tai kansallispuvun tapaan käytetyn muun kotiseudun leimallisen asun käyttäminen nostaa yksilön karjalaisuutta korostavan identiteetin myös ympäristön nähtäväksi. (Ilonen 2006, 27.)

Kaikki vanhimman sukupolven edustajat käyttivät puhuessaan murreilmaisuja, toiset enemmän ja toiset vähemmän täydellistä jonkin osa-alueen kannakselaista murretta. Murre muuttui haastattelun kuluessa täydellisemmäksi eli siihen sekoittui yhä vähemmän muun murreryhmän tai yleiskielen ilmauksia. Eniten uhattuna murre on ollut evakkouden alkuaikoina. Kun evakot tulivat muille Suomen alueille, he olivat vähemmistön asemassa ja alttiina kiusaamiselle. Lapset kokivat koulussa ja vapaa-aikana kiusaamista, mutta oppivat vanhempiaan nopeammin paikallisen puhetavan.

\section{RAJA MÄÄRITTÄÄ KANNAKSELAISUUDEN JA KANNAKSELAISEN IDENTITEETTITYÖN}

Valtakunnan raja määrittää kannakselaisen peruskokemuksen. Raja rajoittaa liikkumista ja arjen toimintoja. Se sävyttää ajatuksia sekä yksilöllisiä, sosiaalisia, kulttuurisia ja aatteellisia näkemyksiä. Rajan kammolla on juurensa perinnetiedossa, joka perustuu vuosisatojen aikana läpikäytyihin identiteettikriiseihin ja sitä vahvistivat Kannaksella eläneiden omat kokemukset ennen viime sotia, sotien aikana ja sotien jälkeen. Rajaseudun asukkaiden lisäksi Kannaksen pohjoisemmilla alueilla eläneet ilmaisivat hekin rajan merkityksen vähintään tunnetasolla. Evakkojen ja myös jälkipolvien mieliin rajan saattoi havaita kirjoitetun hyvin syvälle.
RAja RAJOITTAa

LIIKKUMISTA JA ARJEN

TOIMINTOJA. SE SÄVYTT $\ddot{A} \ddot{A}$

AJATUKSIA SEK $\ddot{A}$

YKSILÖLLISI $\ddot{A}$, SOSIAALISIA,

KULTTUURISIA JA

\section{AATTEELLISIA NÄKEMYKSÏ̈.}

Ei ole pois suljettu, että vaistonomainen, suvun kertomuksista ja omista kokemuksista erillään oleva informaatio periytyy ikään kuin äidinmaidosta saatuna valmiutena kammoon. Viime vuosina tehdyt epigeneettiset ${ }^{10}$ löydökset (esim. Harper 2005; O’Brien 2007; Carey 2011) viittaavat identiteettitasoon, joka on perimänä vahvempi kuin sanojen, käytöksen tai tunteiden ilmaisun kautta hankittu asenne.

Kannakselaisten reflektiota identiteetistään sävyttävät yhteiset poikkeuksellisen merkittävät kokemukset, kuten kodin jättämisen pakko. Vaikka evakkosukupolvi on kertonut paljon, jotain merkittävää on jäänyt kertomatta. Kodin jättämisen hetkeen evakkomatkan alussa liittyvästä tunnetilasta ei yksikään vanhimman sukupolven edustaja maininnut. Sitä tuskin voi tulkita tunteen puuttumiseksi tai välinpitämättömyydeksi.

Evakkokuvausten kirjoittajat ja tutkijat ovat havainneet omissa aineistoissaan vastaavaa vaikenemista (esim. Kivimäki 1999, 5; Lähteenmäki 1999, 220-223; Meinander 2008, 189-201). Sitä on sanottu kollektiiviseksi traumaksi sekä tutkittu myös psykiatrisin keinoin ${ }^{11}$ (Hautamäki 1988). Kaikki vaikeneminen Suomen evakkojen ja sotilaiden kokemusten jälkeen ei ole kuitenkaan ollut seurausta pelkästään henkisestä traumasta, vaan sodan jälkeen ja myöhemminkin niin sanotun kylmän sodan aikana myös yhteiskunta vaati vaikenemista maan turvallisuuden takia (vrt. Virolainen 1989, 260-262).

Tutkimuksen tulokset antoivat viitteitä siihen, että evakkojen rajakokemus on osa myös jälkipolvien psyykeä ja mentaliteettia. Rajan kokemiseen kohdentuvan tutkimuksen avulla kenties saataisiin selville, 
onko tai missä määrin rajatrauma on periytynyt evakkojen lapsille ja lastenlapsille. Joka tapauksessa koettu raja on tosiasia sekä vanhemmilta välittyneenä että itse hankittuna kokemuksena esimerkiksi kotiseutumatkojen tai kannakselaisen yhteisöllisyyden kautta. Raja ei erota vain alueita toisistaan - se on kannakselaisen identiteettityön kokemuksellinen, sosiaalinen, kulttuurinen ja poliittinen konteksti.

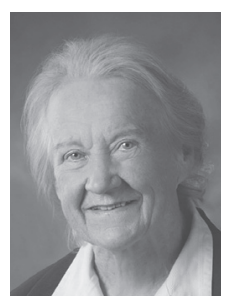

Anneli Ilonen

kasvatustieteen tohtori

Kuva: Studio Tapio

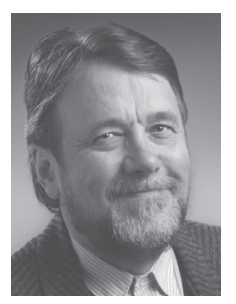

Esa Poikela

kasvatustieteen professori

Lapin yliopisto

\section{LÄHTEET}

Ahokas, 0. (2004). Karjalan kannaksen evakuointi Evakuointisuunnielmat 1922-1944 ja evakuointien karu todellisuus. Tampere: Pilot-Kustannus Oy.

Anttila, J. (2007). Kansallinen identiteetti ja suomalaiseksi samaistuminen. Helsingin yliopiston sosiaalipsykologian laitos.

Carey, N. (2011). The epigenetics revolution: how modern biology is rewriting our understanding of genetics, disease and in heritance. London: Icon.

Denzin, N. K. \& Lincoln, Y. S. (toim.) (2000). Handbook of qualitative research. Oaks (Calif): Sage.

Engman, M. (2007). Raja. Karjalankannas 1918-1920. WSOY

Eskola, J. (2000). Haastattelu ja ryhmähaastattelu. Teoksessa Eskola, J. \& Suoranta, J. (toim.) Johdatus laadulliseen tutkimukseen. Jyväskylä: Vastapaino, 85-94.

Fingerroos, O., Haanpää, R., Heimo, A. \& Peltonen, U-M. (2006). Muistitietotutkimus. Metodologisia kysymyksiä. Helsinki: SKS.

Harper, L.W. (2005). Epigenetic Inheritance and the International Transfer of Experience. Psycholocigal Bulletin 131(3), 340-360.

Hautamäki, S. (1988). Ydintrauma, Ihminen Hiroshiman jälkeen. Oulu. Prometheus.

Hietala, M. (1982). Karjalan koulut - avain Eurooppaan teoksessa Karjala 3 Karjalan yhteiskunta ja talous. Hämeenlinna: Karisto, 53-70.

Honko, L. (1988). Tradition and cultural identity. Turku: Nordic Institute of Folklore.

Houtsonen, J. (1996). Koulutusidentiteetin kulttuurisen rakentumisen ainekset: identiteettien tyypittelyt ja elämänkerralliset teemat teoksessa Antikainen, A. \& Huotelin, H. (toim.) Oppiminen ja elämänhistoria. Aikuiskasvatuksen 37. Vuosikirja. Helsinki: Kansanvalistusseura ja Aikuiskasvatuksen tutkimusseura, 199-216.

Huotelin, H. (1996). Menetelmällisiä lähtökohtia elämäkertatutkimukseen teoksessa Antikainen, A. \& Huotelin, H. (toim.) Oppiminen ja elämänhistoria. Aikuiskasvatuksen 37. Vuosikirja. Helsinki: Kansanvalistusseura ja Aikuiskasvatuksen tutkimusseura, 13-42.

Huttunen, R. (1998). Perusteen periaate ja diskurssiperiaate yliopistossa teoksessa Laitinen, A. (toim.) Normatiivisuuden lähteet. Filosofian julkaisuja 64. Jyväskylän yliopisto, 83-96.

Hämynen, T. (toim.) (1994). Kahden Karjalan välillä. Kahden riikin riitamailla. Studia Carelica Humanistica 5. Joensuun yliopiston humanistinen tiedekunta.

Ilonen, A. (2006). Kansallispuku - identiteetin tunnus. Karelia Klubi 11 Huhtikuu 2006, 27. 
Ilonen, A. (2013). Rajan lapset. Identiteettityö Kannaksen evakkojen sukupolvissa. Acta Universitatis Lapponiensis 258. Rovaniemi: Lapin yliopistokustannus.

Kant, I. (1990). Siveysopilliset pääteokset. Juva: WSOY.

Kauppila, J. (1996). Koulutus elämänkulun rakentajana. teoksessa Antikainen, A. \& Huotelin, H. (toim.) Oppiminen ja elämänhistoria. Aikuiskasvatuksen 37. Vuosikirja. Helsinki: Kansanvalistusseura ja Aikuiskasvatuksen tutkimusseura, 45-108.

Kirkinen, H. (1998). Keitä karjalaiset ovat? teoksessa Nevalainen, P. \& Sihvo, H. (toim.) Karjala. Historia, kansa, kulttuuri. Helsinki: Suomalaisen Kirjallisuuden Seuran Toimituksia 705, 38-54.

Kivimäki, S. (1999). Muistojen aitanrappusilla. Karjalan kannaksen suomalaisen kansanrakentamisen historiaa, nykytilan kartoitus ja esimerkkikohteiden dokumentointi. Diplomityö arkkitehtitutkintoa varten Otaniemessä 1.3.1999. Teknillinen Korkeakoulu Arkkitehtiosasto.

Koiranen, V. A. (1966). Suomalaisten siirtolaisten sulautuminen Ruotsissa. Sosiologinen tutkimus Ruotsiin vuosina 1945-1959 muuttaneiden suomenkielisten siirtolaisten kulttuurin muuttumisesta. Helsinki: WSOY.

Koponen, P. (1999). Karjalan Kirkkokummut. Helsinki: Tammi.

Kujala, E. (2003). Sodan pojat. Sodanaikaisten pikkupoikien lapsuuskokemuksia isyyden näkökulmasta. Jyväskylä: Jyväskylän yliopisto.

Lehtonen, M. (1999). Johdanto teoksessa Stuardt Hall Identiteetti. Suomentanut ja toimittanut Lehtonen, M. \& Herkman, J. Tampere: Vastapaino.

Liebkind, K. (1988). Me ja muukalaiset - Ryhmärajat ihmisten suhteissa. Helsinki: Caudeamus.

Lähteenmäki, M. (1999). Jänkäjääkäreitä ja parakkipiikoja Lappilaisten sotakokemuksia 19391945. Helsinki: Suomen Historiallinen Seura.

Mannheim K. (1972). The problem of Generations teoksessa Kecskemeti, P. (toim.) Essays on the Sociology of Knowledge. London: Routledge \& Kegan Paul Ltd, 276-320.

Meinander, H. (2008). Suomi 1944. Sota, yhteiskunta, tunnemaisema. Autio, P. (suom.) Helsinki: Osakeyhtiö Valistus.

Metsämuuronen, J. (2007). Tutkimuksen tekemisen perusteet ihmistieteissä. 4. Painos. Helsinki: International Methelp Ky.

Mäkinen, Y-P. (1982). Salmin kihlakunta teoksessa Mäkinen, Y.-P. \& Lehmusvaara, I. (toim.) Karjala 3 Karjalan yheiskunta ja talous. Hämeenlinna: Arvi A. Karisto Oy.
O'Brien, K. (2007). The uncounted casualties of war: epigenetics and the intergenerational transference of PTSD symptoms among children and grandchildren of Vietnam veterans in Australia. Brisbane: Queensland University of Techonology.

Paasi, A. (1984). Alueellisen identiteetin sosiaalinen sisältö. Suomen Antropologia 2, 50-58.

Paavolainen, E. (1960). Sellainen oli Karjala. Luovutetun alueen vaiheita. 2. painos. Helsinki: Otava.

Purhonen, S. (2007). Sukupolvien ongelma. Tutkielmia sukupolven käsitteestä, sukupolvitietoisuudesta ja suurista ikäluokista. Akateeminen väitöskirja. Helsingin yliopiston sosiologian laitoksen tutkimuksia nro 251. Helsingin yliopisto.

Raivo, P. J. (1998). Karjalan kasvot: Näkökulmia Karjalan maisemaan teoksessa Nevalainen, P. \& Sihvo, H. (toim.) Karjala Historia, kansa, kulttuuri. Helsinki SKS, 11-27.

Raninen-Siiskonen, T. (1999). Vieraana omalla maalla. Tutkimus karjalaisen siirtoväen muistelukerronnasta. Helsinki Suomalaisen Kirjallisuuden Seura.

Roos, J.-P. (1987). Suomalainen elämä. Tutkimus tavallisten suomalaisten elämäkerroista. Hämeenlinna: SKS:n toimituksia 454.

Sallinen-Gimpl, P. (1989). Karjalainen kulttuuriidentiteetti teoksessa Korhonen, T. \& Räsänen, M. (toim.) Kansa kuvastimessa - Etnisyys ja identiteetti. Helsinki: SKS, 209-226.

Simonen, S. (1965). Paluu Karjalaan. Palautetun alueen historia 1941-1944. Helsinki: Kustanusosakeyhtiö Otava.

Tuomi, J. \& Sarajärvi, A. (2009). Laadullinen tutkimus ja sisällönanalyysi. Helsinki: Tammi.

Uino, P. (2003). Karjalan arkeologiaa 150 vuotta teoksessa Saarnisto, M. (toim.) Viipurin läänin historia I. Karjalan synty. Jyväskylä: Gummerus Kirjapaino Oy, 117-150.

Waris, H. (1952). Siirtoväen sopeutuminen. Tutkimus Suomen karjalaisen siirtoväen sosiaalisesta sopeutumisesta. Helsinki: Otava.

Wenger, E. (1999). Communities of practice: learning, meaning, and identity. Cambridge: Cambridge University Press.

Virolainen, J. (1989). Siirtokarjalaiset 1942-1944 Kotiinpaluu, jälleenrakennus, uusi lähtö. Helsinki: Kustannusosakeyhtiö Otava.

Virtanen, L. (1987). Monta Karjalaa teoksessa Pulliainen, K. \& Sihvo, H. (toim.) Carelia rediviva juhlakirja professori Heikki Kirkiselle 22.9.1987. Joensuun yliopiston tukisäätiö. Joensuu: Karjalaisen kulttuurin Edistämissäätiö, 179-186. 
1 Käsite kuvastaa kannakselaisten kokemusta poliittisesta, historiallisesta ja moraalisesta oikeutuksesta liittyen alueen hallintaan.

2 Katso myös kokoomateos Kahden Karjalan välillä (toim. Hämynen 1994).

3 Kokemuksellisten sukupolvien rinnalla on alun perin tilastotieteessä käytetty käsitettä kohortti, jossa kronologinen ikä on yhteiskunnallista tai kokemuksellista sukupolvea merkittävämpi tekijä. Kohortti-käsitettä on esiintynyt myös sosiologian klassikkojen teksteissä.

4 Imperatiivi on kategorinen, koska siitä on tullut itsessään kaikkea ajattelua ja toimintaa säätelevä maksiimi (lainomainen perusperiaate). Jos imperatiivi olisi vain välineellinen, se olisi hypoteettinen olleessaan alisteinen jotakin muuta tarkoitusta varten. (vrt. Huttunen 1998.) Esimerkiksi ajatusta Karjalan palauttamisesta voidaan tarkastella hypoteettisena, mikäli se alistetaan politiikan yleisille päämäärille. Sen sijaan se on kategorinen siirtokarjalaisiksi pakotetuille kannakselaisille määrittäessään heidän kaikkia elämänkohtaloitaan.

5 Neljäs sukupolvi jäi edustavuudessaan kuriositeetiksi hyvin nuoren ikänsä takia.

6 Teemat jäsentyivät vanhimman sukupolven avoimien haastatteluiden pohjalta.

7 Kokemukseen ja muistiin perustuvan tiedon tutkimisesta esim. Fingerroos ym. (2006).

8 Aineisto koodattiin siten, että sitaatista voi todentaa, miltä seudulta, paikkakunnalta ja mihin sukupolveen haastateltava kuuluu ja miltä litteroidulta sivulta alkuperäinen ilmaus löytyy.

9 Viranomaisten estelyistä huolimatta kannakselaiset halusivat palata kotisijoilleen saadakseen pellot tuottamaan ruokaa, josta oli pula koko maassa. Kaikkiaan Karjalassa palaajia oli 280000 ja jälleenrakentaminen tapahtui vuosina 1941-1944 sodan äänien kuuluessa joka päivä (Simonen 1965; Virolainen 1989]. Tutkimuksessa haastatelluista evakoista suurin osa kuului palanneisiin ja he joutuivat siten tekemään kaksi evakkomatkaa.

10 Esimerkiksi kaksostutkimukset osoittavat, että ihmisellä on erityisiä herkkyysgeenejä, eräänlaisia on-/off-geenejä, jotka virittyvät tai jäävät virittymättä ympäristötekijöiden vaikutuksesta.

11 Muun muassa eloon jääneiden Hiroshiman atomipommin uhrien kokemukset. 